\title{
LASER VERSUS CONVENTIONAL SURGICAL TECHNIQUES TO UNCOVER DENTAL IMPLANTS IN THE SECOND-STAGE SURGERY
}

\author{
Ahmed T. Temerek*, Ali Fahd"*, Ola Rehan ${ }^{* * *}$, \\ Youssef AbdElGhaffar ${ }^{* * * *}$ and Hanaa El-Shenawy ${ }^{* * * * *}$
}

\begin{abstract}
Statement of Problem: This review investigates laser benefits in second stage dental implant surgery as compared to conventional methods. Methods of Study: An electronic database search on PubMed, Cochrane library and LILACS for clinical studies in which laser was used for the second-stage implant surgery were selected and evaluated. Results: initial search yielded 136 studies, 15 were considered potentially relevant, out of which only three were finally selected. They studied the effect of laser on postoperative pain, the need for anesthesia and analgesia, hemostasis, time needed before impression and quality of it, duration of surgery and peri-implant soft tissue conditions. The results shows that the assessed studies are too limited in number beside exhibiting small sample sizes. They are clinically heterogeneous so that a solid conclusion cannot be reached. Conclusions: Researchers should be attracted to laser use to close a very obvious research gap. Randomized clinical trials are strongly recommended.
\end{abstract}

KEY WORDS: Laser, Implant surgery, Second-stage, Implant exposure, Systematic review.

\section{INTRODUCTION}

Despite the long history of dental implants, the development of implant science is still a major research subject. Dental implantology has been constantly improving in the recent years, providing higher levels of patient satisfactions ${ }^{(1)}$.
The second-stage surgery for uncovering submerged dental implants can be performed by different tools and techniques with pros and cons for each technique. For example, the use of scalpel is associated with some bleeding, pain, and discomfort while electrosurgery may cause damaging to the implant surface affecting the osseointegration ${ }^{(2)}$.

\footnotetext{
* Lecturer, Oral and Maxillofacial surgery, Faculty of oral and dental medicine, South Valley University, Qena, Egypt.

** Lecturer, Oral and Maxillofacial Radiology Department, Faculty of Oral and Dental Medicine, South Valley University, Qena, Egypt.

*** Lecturer, Oral and Maxillofacial Radiology Department, Faculty of Oral and Dental Medicine, Cairo University, Cairo, Egypt.

**** Lecturer, Periodontics Department, Faculty of Oral and Dental Medicine, MUST University, Egypt.

***** Associate Professor, Oral Medicine, National Research Centre, Cairo, Egypt.
} 
Using laser in dental surgeries offers improved vision because of homeostasis, less mechanical trauma to tissues, reduced need for anaesthesia, reduced local infection and inflammation, reduced post-operative pain and improved healing ${ }^{(2,3)}$. However, the use of laser in dental implant surgeries is a source of controversy because of worry about preserving keratinized tissues, the cost, the technique used and the increase in peri-implant bone temperature ${ }^{(4,10)}$.

The main objective of this review is to describe and evaluate the use of laser in the second-stage surgery for uncovering dental implant in comparison to other conventional techniques. Is using laser for second stage implant surgery is recommended over conventional techniques?

\section{MATERIALS AND METHODS}

\section{Protocol}

The methods as well as inclusion/exclusion criteria employed for the present review were determined in advance. The current systematic review was performed following the PRISMA guidelines for identification, screening, eligibility, and inclusion ${ }^{(11)}$. The following focus question was developed: In patient requiring uncovering dental implants regarding the use of laser versus conventional techniques, what is the evidence based recommendation for both patients and operators?

This study was approved by the ethics and research committee in our institute

\section{Information sources}

The electronic search was performed in four databases, including MEDLINE (PubMed), Cochrane library and LILACS databases for articles with no date restrictions.

\section{Search}

The researched keywords were: (oral implant
OR oral implantology OR dental implantology OR dental implant OR dental implantation)AND (second stage OR second-stage OR uncover OR exposure OR punch OR second phase OR uncovering) AND conventional tequnique OR scalpel surgery (laser)

\section{Selection of studies}

Titles and abstracts resulted from the search were screened by authors considering the inclusion criteria. Authors decisions about choices and their qualification for further analysis was affirmed after discussion.

\section{Inclusion and exclusion criteria}

Inclusion criteria:

- Clinical studies only

- In vivo studies

\section{Exclusion criteria:}

- In vitro and animal studies

- Reviews

- $\quad$ Case reports

- Languages other than English

\section{Assessment of methodological quality}

The quality of all chosen randomized trials was investigated utilizing The Cochrane Collaboration's tool for evaluating risk of bias (12) while the Newcastle-Ottawa Scale (NOS) was used for nonrandomized studies (13).

According to Cochrane risk of bias tools, each RCT was assigned either; low risk of bias (if it is low for all key domains), high risk of bias (if it is high for one or more of key domains) and unclear risk of bias (if it is unclear for one or more of key domains). Because it was impossible to blind participants or personnel due to nature of intervention and control (i.e. Laser VS surgery), the "BLINDING OF PARTICIPANTS, PERSONNEL" item was not considered. 
For non-randomized controlled trials, the assessment consists of 3 sections; The selection section included 4 items, with 1 star for each item, Comparability section included 1 item with almost 2 stars for this item and outcome included 3 items with 1 star at each item. The total quality score represents the quality of the study. If the total number of stars was less than 5, the study was low quality, Otherwise, it was a high-quality study.

The heterogeneity between trials prevented meta-analysis. Rather, a descriptive analysis of the reported studies was performed.

\section{RESULTS}

Out of the initial search that yielded 136 studies, 15 were considered potentially relevant for the present study, out of which 3 were finally selected. Figure (1) represents the flow chart for the study. The excluded studies before final inclusion were either case reports $(8,14)$, uncontrolled studies or no study design (15-17), reviews (18-20), experimental and in vitro studies (21-23) and in Russian language (24).

The included trials which matches the inclusion criteria evaluate the effect of laser on postoperative

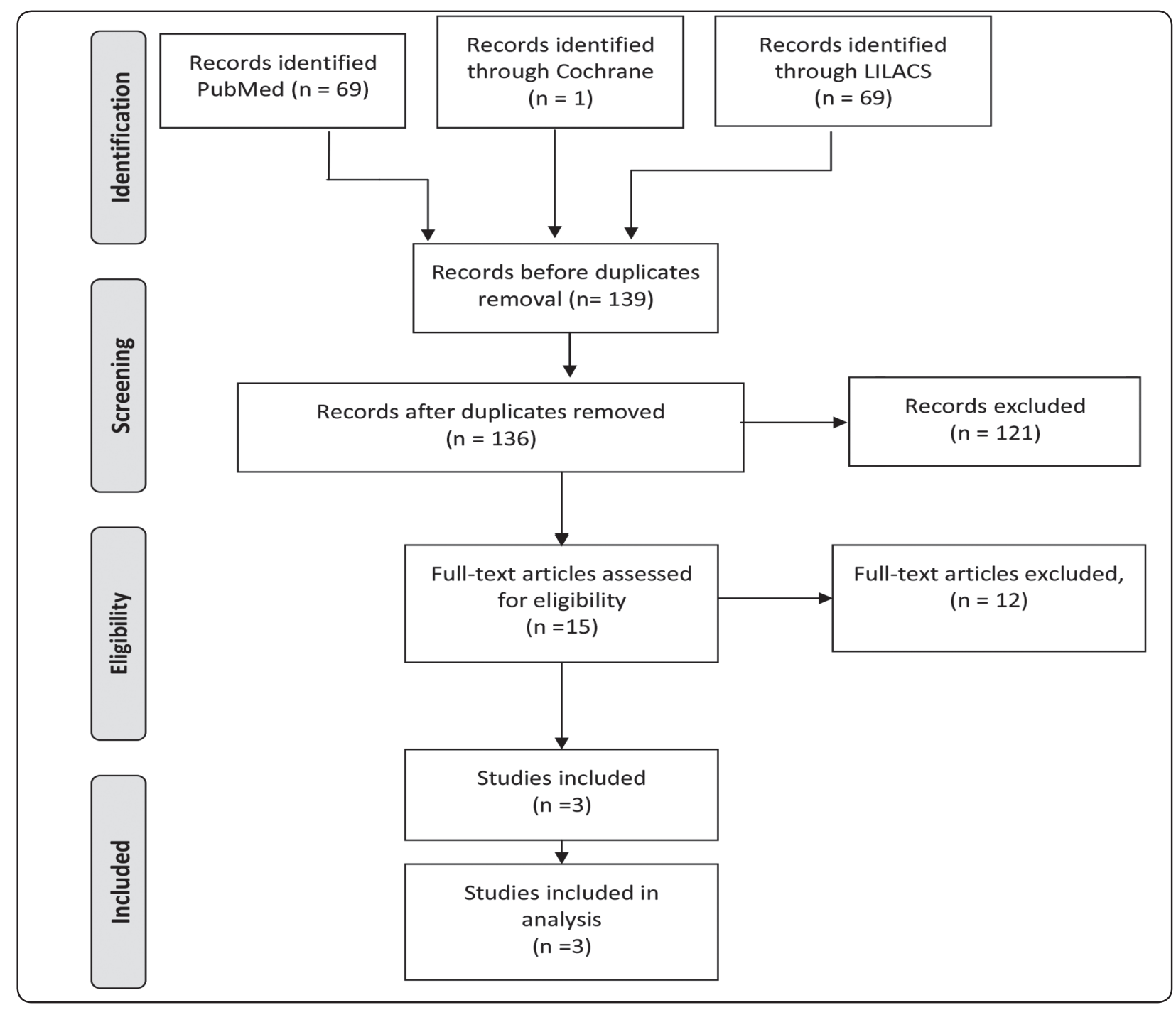

Fig. (1): PRISMA flow chart for the study 
pain, the need for anesthesia and analgesia, hemostasis, time needed before impression and quality of it, duration of surgery and peri-implant soft tissue conditions $(2,5,25)$. Table (1) represents summary of findings.

\section{Risk of bias within studies:}

The review included three studies, two of them were $\operatorname{RCT}(2,5)$ and one was prospective controlled trial ${ }^{(25)}$. The study of Matys and Dominiak 2016 (25) used split mouth study design and the studies of Arnabat-Domínguez et al $2003^{(5)}$ and El-Kholey $2013^{(2)}$ used parallel design. Sex distribution was mentioned in the studies of Matys and Dominiak (25) and El-Kholey ${ }^{(2)}$ and not mentioned in the study of Arnabat-Domínguez et al ${ }^{(5)}$.

For RCT studies, according to Cochrane Risk

TABLE 1. Summary of findings table (SOFT). of Bias Tool, both studies were judged to be low risk of bias for random sequence generation, incomplete outcome data and selective reporting. Regarding allocation concealment, El-kholy 2013 (2) was judged as low risk of bias while it was judged as unclear for Arnabat-Domínguez et al 2003 (5) as it did not mention anything about allocation concealment. Regarding Blinding of outcome assessment, both studies were judged as unclear as there was no mention about blinding of the assessor or statistician. Both studies were considered overall as unclear risk of bias. Evaluation of risk of bias is in figures (2 and 3).

For non-randomized controlled trial, Matys and Dominiak 2016 study ${ }^{(25)}$ was considered to be of high quality. Evaluation of study quality is in table (2).

\begin{tabular}{|c|c|c|c|c|c|}
\hline $\begin{array}{l}\text { Authors and } \\
\text { date }\end{array}$ & Population & $\begin{array}{l}\text { Intervention } \\
\text { (Laser) }\end{array}$ & Control & Outcome & Results \\
\hline $\begin{array}{l}\text { Arnabat- } \\
\text { Dominguez } \\
\text { et al } 2003\end{array}$ & $\begin{array}{l}20 \text { patients with } \\
50 \text { implants in } \\
\text { the second stage } \\
\text { surgery divided } \\
\text { into two equal } \\
\text { groups of } 10 \\
\text { patients each }\end{array}$ & $\begin{array}{l}\text { Erbium laser } \\
\text { was used to } \\
\text { expose the } \\
\text { implants }\end{array}$ & $\begin{array}{l}\text { Conventional } \\
\text { blade incision } \\
\text { and flap } \\
\text { elevation }\end{array}$ & $\begin{array}{l}\text { Postoperative pain, } \\
\text { duration of surgery, consumption } \\
\text { of analgesics, need of anesthesia, } \\
\text { conditions of the peri-implant } \\
\text { soft tissues, quality of } \\
\text { hemostasis, success of treatment } \\
\text { and days to start the prosthetic } \\
\text { rehabilitation }\end{array}$ & $\begin{array}{l}\text { The use of laser obviated } \\
\text { the need for local } \\
\text { anesthesia and minimized } \\
\text { postoperative pain and } \\
\text { time neededbefore } \\
\text { starting the second stage. } \\
\text { No significant differences } \\
\text { in other parameters }\end{array}$ \\
\hline $\begin{array}{l}\text { El-Kholey } \\
2013\end{array}$ & $\begin{array}{l}30 \text { patients with } \\
45 \text { implants in } \\
\text { the second stage } \\
\text { surgery divided } \\
\text { into two equal } \\
\text { groups of } 15 \\
\text { patients each }\end{array}$ & $\begin{array}{l}\text { Diode laser } \\
\text { was used to } \\
\text { expose the } \\
\text { implants }\end{array}$ & $\begin{array}{l}\text { The scalpel } \\
\text { was used to } \\
\text { expose the } \\
\text { implants }\end{array}$ & $\begin{array}{l}\text { The need for infiltration } \\
\text { anaesthesia, duration of surgery, } \\
\text { intraoperative bleeding, } \\
\text { postoperative pain and time } \\
\text { before impression taking }\end{array}$ & $\begin{array}{l}\text { The use of laser obviated } \\
\text { the need for local } \\
\text { anaesthesia } \\
\text { No significant differences } \\
\text { in other parameters }\end{array}$ \\
\hline $\begin{array}{l}\text { Matys and } \\
\text { Dominiak } \\
2016\end{array}$ & $\begin{array}{l}30 \text { patients with } \\
60 \text { implants in } \\
\text { the second stage } \\
\text { surgery divided } \\
\text { into two equal } \\
\text { groups of } 30 \\
\text { patients each }\end{array}$ & $\begin{array}{l}\text { Erbium laser } \\
\text { was used to } \\
\text { expose the } \\
\text { implants }\end{array}$ & $\begin{array}{l}\text { The scalpel } \\
\text { was used to } \\
\text { expose the } \\
\text { implants }\end{array}$ & $\begin{array}{l}\text { Pain level and quality of the } \\
\text { impression of the } \\
\text { implant emergence profile. }\end{array}$ & $\begin{array}{l}\text { The use of laser reduces } \\
\text { pain and allows minor } \\
\text { surgical procedures } \\
\text { to be carried out } \\
\text { without anesthesia. } \\
\text { The impression quality } \\
\text { is satisfactory for the } \\
\text { preparation of prosthetic } \\
\text { reconstructions }\end{array}$ \\
\hline
\end{tabular}


TABLE 2. Quality assessment for non-randomized clinical trials

\begin{tabular}{|l|c|}
\hline & $\begin{array}{c}\text { Matys, and Dominiak } \\
2016(25)\end{array}$ \\
\hline $\begin{array}{l}\text { Representativeness of the treatment group (true representation of the average in the community or } \\
\text { somewhat representative of the average in the community) }\end{array}$ & + \\
\hline Selection of the untreated control group (drawn from the same community of the treated group) & + \\
\hline Ascertainment of treatment group & + \\
\hline Demonstration that the outcome of interest was not present at the day of start (yes) & + \\
\hline $\begin{array}{l}\text { Comparability of the group and control group (comparison of starting forms: baseline characteristics of } \\
\text { age, sex) }\end{array}$ & - \\
\hline Assessment of the outcome with independent blinding (independent blind assessment) & + \\
\hline $\begin{array}{l}\text { Was follow-up adequate enough for outcomes to occur? (Yes, an adequate follow up for short-term } \\
\text { findings) }\end{array}$ & + \\
\hline $\begin{array}{l}\text { Loss to follow-up acceptable (complete follow-up, subjects lost to follow-up unlikely to introduce bias, } \\
\text { description provided of those lost, small number of loss to follow up } \backslash 10 \%)\end{array}$ & 6 \\
\hline Total quality score & \\
\hline
\end{tabular}

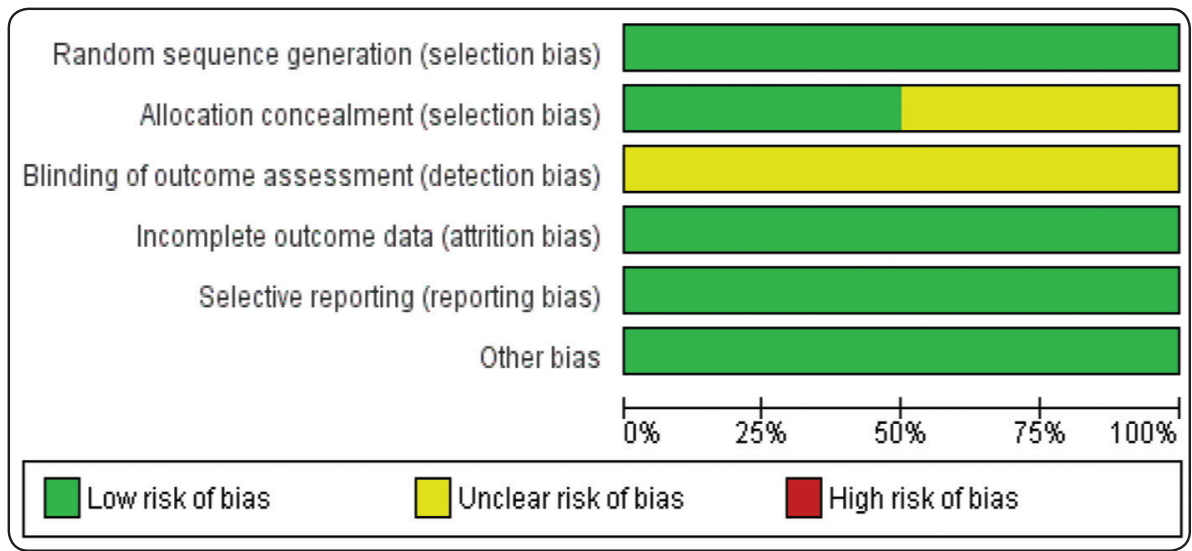

Fig. (2): Risk of bias summary: review authors" judgements about each risk of bias item for each included RCT study.

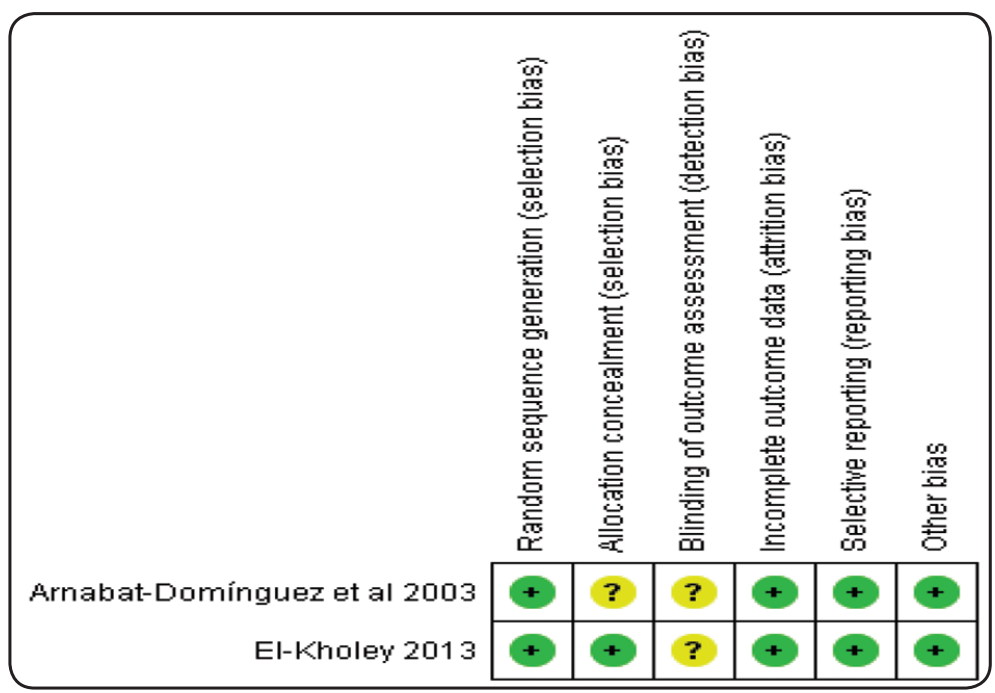

Fig. (3): Risk of bias graph: review authors" judgements about each risk of bias item presented as percentages across all included RCT studies. 


\section{DISCUSSION}

Lasers can be used as a current alternative to the traditional scalpel in oral soft tissue surgeries because it offers simple manipulation as regards to absence of bleeding, reduced need for local anesthesia and increased patient comfort ${ }^{(8)}$. From that points of view comes the research question, why not to recommend over conventional techniques regarding second stage implant surgery. For the surgeons, factors of concern in dental implantology are the adequate surgical techniques and the adequate materials, while for the patient the postoperative status and survival rate of the implants are the main target ${ }^{(26)}$. Laser can give both what they target.

Yeh et al concluded that laser can be used as an alternative tool in second-stage implant surgery for the advantages of being efficient, safe, and patient-friendly technique that also allows a faster rehabilitation phase ${ }^{(4)}$. Their work was a case report with two patients so it is not included in this systematic review.

Although carbon dioxide $\left(\mathrm{CO}_{2}\right)$ laser is widely used in oral surgeries ${ }^{(27,28)}$, some authors recommend its avoidance in implantology because of its thermal effects while others use it without complications ${ }^{(29,31)}$. On the other hand, other types of laser like the Erbium laser can be applied safely ${ }^{(32)}$. In secondstage implant surgery, Erbium laser is not only used in soft tissue manipulation but also to ablate bone that may form around the healing cap ${ }^{(33)}$.

The concern about the damaging effect due to temperature increase in implant bone interface as a result of laser application has been investigated and there is evidence that the also the diode laser group is safe and not badly affecting neither the implant nor the bone ${ }^{(2,6,34-36)}$. The cause may be the wavelength, the minimal depth of penetration, and the reflection of the laser away from the dental implant surface $^{(34,37,38)}$. In implant dentistry, keratinized gingiva for peri-implant health and superior esthetic results may be a target and the role of laser in that part is a point of debate $(5,8,39,40)$.
The study of Arnabat-Domínguez et offers a solution not only for the problem of heat generation but also for preservation of the attached keratinized gingiva, by using the non-thermal erbium laser in doing a trapezoidal flap for uncovering the implant thus allowing apical repositioning and transpositioning of keratinized gingiva ${ }^{(8)}$. Minimized postoperative pain, shortened time to prosthetic rehabilitation and superior esthetics were the results of their three cases report. Again, this work was not included for being done only in three cases.

For a patient relevant treatment outcome, pain after implant surgeries is of concern not only for the patient but also for the dentist. Patients will experience pain following dental implant surgery as with any other dental surgical procedures ${ }^{(41,43)}$. Despite that the second-stage implant surgery is not as aggressive as the first-stage implant surgery, it may involve as much postoperative discomfort for the patients as the first-stage ${ }^{(5)}$.

Pain reduction after dental implant surgeries should motivate researchers because in the literature there is still a research gap in the management of pain associated with dental implant surgeries in contrast to the greater proportion of studies investigating management of post-operative pain after common dental surgical procedure like thirdmolar extraction ${ }^{(41,44,45)}$.

The Laser effect in pain reduction during soft tissue surgery may be due to the creation of a protein coagulation protective layer or due to the sealing of nerve endings ${ }^{25)}$. Fear of pain during dental surgeries or even the needle used for anesthesia are among the causes of avoiding dental visits ${ }^{(25)}$.

Arnabat-Dominguez et al (5) compared laser use for implant exposure to the conventional flap elevation. Patients on the laser group did not receive local anesthesia except for two patients. Patients treated with laser not only experienced less postoperative pain and consumed significantly 
less analgesics but also the prosthetic procedures could start earlier than the conventional flap group. Although their results support laser over control, the choice of elevating flap as a control group is questionable. It is not clear why the authors did not use the punch technique or the $\mathrm{H}$ incision technique instead of elevating the flap in the control group ${ }^{(9)}$.

The lack of standardization in studies not only for the samples but also for the methods and parameters complicate the determination of the efficiency of laser as regards to surgical models ${ }^{(46)}$. This has been shown clearly by the results of this systematic review. Randomized clinical trials in each aspect of laser applicationsin dental implants should motivate researchers to close a very interesting research gaps.

The found clinical studies are not only too limited in number but also exhibit small sample sizes, besides being clinically heterogeneous so that a solid conclusion cannot be reached. researchers should pay attention to this interesting field to work upon. Each kind of laser application should pull attention of researchers in oral and maxillofacial field to close obvious, yet important, research gaps of lack of enough randomized clinical trials that can be relied upon to get a standard evidence based clinical practice.

\section{REFERENCES}

1. Gaviria L, Salcido JP, Guda T, Ong JL. Current trends in dental implants. Journal of the Korean Association of Oral and Maxillofacial Surgeons. 2014;40(2):50-60.

2. El-Kholey K.Efficacy and safety of a diode laser in secondstage implant surgery: a comparative study. International journal of oral and maxillofacial surgery. 2014;43(5):6338 .

3. Strauss RA, Fallon SD. Lasers in contemporary oral and maxillofacial surgery. Dent Clin North Am. 2004 Oct;48(4):861-88, vi. PubMed PMID: 15464556. Epub 2004/10/07. eng.

4. Yeh S, Jain K, Andreana S. Using a diode laser to uncover dental implants in second-stage surgery. General dentistry. 2005;53(6):414.
5. Arnabat-Domínguez J, España-Tost AJ, Berini-Aytés L, Gay-Escoda C. Erbium: YAG laser application in the second phase of implant surgery: a pilot study in 20 patients. International Journal of Oral \& Maxillofacial Implants. 2003;18(1).

6. Romanos GE, Everts H, Nentwig GH. Effects of diode and Nd: YAG laser irradiation on titanium discs: a scanning electron microscope examination. Journal of periodontology. 2000;71(5):810-5.

7. Kreisler M, Götz H, Duschner H, d'Hoedt B. Effect of Nd: YAG, Ho: YAG, Er: YAG, CO 2, and GaAlAs Laser Irradiation on Surface Properties of Endosseous Dental Implants. International Journal of Oral \& Maxillofacial Implants. 2002;17(2).

8. Arnabat-Domínguez J, Bragado-Novel M, España-Tost AJ, Berini-Aytés L, Gay-Escoda C. Advantages and esthetic results of erbium, chromium: yttrium-scandium-galliumgarnet laser application in second-stage implant surgery in patients with insufficient gingival attachment: a report of three cases. Lasers in medical science. 2010;25(3):459-64.

9. Esposito M, Maghaireh H, Grusovin MG, Ziounas I, Worthington HV. Interventions for replacing missing teeth: management of soft tissues for dental implants. The Cochrane Library. 2012.

10. Park C-Y, Kim S-G, Kim M-D, Eom T-G, Yoon J-H, Ahn S-G. Surface properties of endosseous dental implants after NdYAG and $\mathrm{CO} 2$ laser treatment at various energies. Journal of oral and maxillofacial surgery. 2005;63(10):1522-7.

11. Moher D, Liberati A, Tetzlaff J, Altman DG. Preferred reporting items for systematic reviews and meta-analyses: the PRISMA statement. International journal of surgery (London, England). 2010;8(5):336-41. PubMed PMID: 20171303. Epub 2010/02/23. Eng.

12. Higgins JP, Altman DG, Gotzsche PC, Juni P, Moher D, Oxman AD, et al. The Cochrane Collaboration's tool for assessing risk of bias in randomised trials. BMJ (Clinical research ed). 2011 Oct 18;343:d5928. PubMed PMID: 22008217. Pubmed Central PMCID: PMC3196245. Epub 2011/10/20. Eng.

13. Stang A. Critical evaluation of the Newcastle-Ottawa scale for the assessment of the quality of nonrandomized studies in meta-analyses. European journal of epidemiology. 2010 Sep;25(9):603-5. PubMed PMID: 20652370. Epub 2010/07/24. Eng. 
14. Yeh S, Jain K, Andreana S. Using a diode laser to uncover dental implants in second-stage surgery. Gen Dent. 2005 Nov-Dec;53(6):414-7. PubMed PMID: 16366049. Epub 2005/12/22. eng.

15. van As G. Uncovering the tooth: the diode laser to uncover teeth, brackets and implants. Dent Today. 2012 Jan;31(1):168. PubMed PMID: 22360126. Epub 2012/03/01. eng.

16. Kusek ER. Tissue-punch technique in nonattached tissue using the YSGG laser. Dent Today. 2009 Jan;28(1):132, 4-5. PubMed PMID: 19323339. Epub 2009/03/28. eng.

17. van As G. The diode laser--The diode laser in second stage implant reovery. Dent Today. 2011 Sep;30(9):144. PubMed PMID: 21980731. Epub 2011/10/11. eng.

18. Esposito M, Grusovin MG, Maghaireh H, Coulthard P, Worthington HV. Interventions for replacing missing teeth: management of soft tissues for dental implants. The Cochrane database of systematic reviews. 2007 Jul 18(3):CD006697. PubMed PMID: 17636847. Epub 2007/07/20. eng.

19. Esposito M, Maghaireh H, Grusovin MG, Ziounas I, Worthington HV. Soft tissue management for dental implants: what are the most effective techniques? A Cochrane systematic review. Eur J Oral Implantol. 2012 Autumn;5(3):221-38. PubMed PMID: 23000707. Epub 2012/09/25. eng.

20. Esposito M, Maghaireh H, Grusovin MG, Ziounas I, Worthington HV. Interventions for replacing missing teeth: management of soft tissues for dental implants. The Cochrane database of systematic reviews. 2012 Feb 15(2):CD006697. PubMed PMID: 22336822. Epub 2012/02/18. eng.

21. Fornaini C, Merigo E, Vescovi P, Bonanini M, Antonietti W, Leoci L, et al. Different laser wavelengths comparison in the second-stage implant surgery: an ex vivo study. Lasers Med Sci. 2015 Aug;30(6):1631-9. PubMed PMID: 24989333. Epub 2014/07/06. eng.

22. Romanos GE, Belikov AV, Skrypnik AV, Feldchtein FI, Smirnov MZ, Altshuler GB. Uncovering dental implants using a new thermo-optically powered (TOP) technology with tissue air-cooling. Lasers Surg Med. 2015 Jul;47(5):411-20. PubMed PMID: 25920077. Epub 2015/04/29. eng.

23. Wilcox CW, Wilwerding TM, Watson P, Morris JT. Use of electrosurgery and lasers in the presence of dental implants. Int J Oral Maxillofac Implants. 2001 Jul-
Aug;16(4):578-82. PubMed PMID: 11516006. Epub 2001/08/23. eng.

24. Kulakov AA, Krechina EK, Kasparov AS, Verzilov EV, Seregin SS. [Impact of various second-stage implant surgery methods on adjacent gingival tissues microcirculation]. Stomatologiia. 2014;93(6):52-6. PubMed PMID: 25588402. Epub 2015/01/16. rus.

25. Matys J, Dominiak M. Assessment of Pain When Uncovering Implants with Er: YAG Laser or Scalpel for Second Stage Surgery. Advances in clinical and experimental medicine: official organ Wroclaw Medical University. 2016;25(6):1179.

26. Yumashev AV, Utyuzh AS, Volchkova IR, Mikhaylova MV, Kristal EA. The Influence of Mesodiencephalic Modulation on the Course of Postoperative Period and Osseointegration Quality in case of Intraosseus Dental Implantation. Indian Journal of Science and Technology. 2016;9(42).

27. Walsh L. The use of lasers in implantology: an overview. The Journal of oral implantology. 1991;18(4):335-40.

28. Wigdor HA, Walsh JT, Featherstone JD, Visuri SR, Fried $\mathrm{D}$, Waldvogel JL. Lasers in dentistry. Lasers in surgery and medicine. 1995;16(2):103-33.

29. Mouhyi J, Sennerby L, Nammour S, Guillaume P, Van Reck J. Temperature increases during surface decontamination of titanium implants using CO2 laser. Clinical oral implants research. 1999;10(1):54-61.

30. Barak S, Horowitz I, Katz J, Oelgiesser D. Thermal Changes in Endosseous Root-Form Implants as a Result of CO 2 Laser Application: An In Vitro and In Vivo Study. International Journal of Oral \& Maxillofacial Implants. 1998;13(5).

31. Spencer P, Cobb CM, Wieliczka DM, Glaros AG, Morris PJ. Change in temperature of subjacent bone during soft tissue laser ablation. Journal of periodontology. 1998;69(11):1278-82.

32. Li ZZ, Reinisch L, Van de Merwe WP. Bone ablation with Er: YAG and CO2 laser: study of thermal and acoustic effects. Lasers in surgery and medicine. 1992;12(1):79-85.

33. Hibst R, Keller U, editors. Heat effect of pulsed Er: YAG laser radiation. OE/LASE'90, 14-19 Jan, Los Angeles, CA; 1990: International Society for Optics and Photonics.

34. Kreisler M, Al Haj H, d'Hoedt B. Temperature changes induced by $809-\mathrm{nm}$ GaAlAs laser at the implant-bone interface during simulated surface decontamination. Clinical oral implants research. 2003;14(1):91-6. 
35. Romanos GE, Everts H, Nentwig G-H. Alterations of the Implant Surface after CO 2-or Nd: YAG-Laser Irradiation: A SEM Examination. Journal of Oral Laser Applications. 2001;1(1).

36. Kato T, Kusakari H, Hoshino E. Bactericidal efficacy of carbon dioxide laser against bacteria-contaminated titanium implant and subsequent cellular adhesion to irradiated area. Lasers in surgery and medicine. 1998;23(5):299-309.

37. Martin E. Lasers in dental implantology. Dental Clinics of North America. 2004;48(4):999-1015.

38. Christensen GJ. Soft-tissue cutting with laser versus electrosurgery. J Am Dent Assoc. 2008;139(7):981-4.

39. Marquez I. The role of keratinized tissue and attached gingiva in maintaining periodontal/peri-implant health. General dentistry. 2003;52(1):74-8; quiz 9.

40. Maksoud MA. Manipulation of the peri-implant tissue for better maintenance: a periodontal perspective. Journal of Oral Implantology. 2003;29(3):120-3.

41. Bryce G, Bomfim D, Bassi G. Pre-and post-operative management of dental implant placement. Part 1: management of post-operative pain. British dental journal. 2014;217(3):123-7.
42. Al-Khabbaz AK, Griffin TJ, Al-Shammari KF. Assessment of pain associated with the surgical placement of dental implants. Journal of periodontology. 2007;78(2):239-46.

43. Hashem AA, Claffey NM, O'Connell B. Pain and anxiety following the placement of dental implants. International Journal of Oral \& Maxillofacial Implants. 2006;21(6).

44. Mohammadi F, Hasheminasab M, Jahandide PP. Effectiveness of low level laser in minimizing edema and promoting wound healing after third molar surgery: a randomized clinical trial. Journal of Craniomaxillofacial Research. 2015;1(2):58-62.

45. Amarillas-Escobar ED, Toranzo-Fernández JM, MartínezRider R, Noyola-Frías MA, Hidalgo-Hurtado JA, Serna $\mathrm{VMF}$, et al. Use of therapeutic laser after surgical removal of impacted lower third molars. Journal of oral and maxillofacial surgery. 2010;68(2):319-24.

46. Sierra SO, Deana AM, Ferrari RAM, Albarello PM, Bussadori SK, Fernandes KPS. Effect of low-level laser therapy on the post-surgical inflammatory process after third molar removal: study protocol for a double-blind randomized controlled trial. Trials. 2013;14(1):1. 